\title{
AN EFFECT OF SYMBOLS ON CONSUMER BEHAVIOUR: THE THEORETICAL INSIGHTS
}

\author{
Gintare KRIAUČIŪNAITĖ-LAZAUSKIENE்(D) ${ }^{*}$, Rima ŽITKIENE்(iD) ${ }^{2}$ \\ 1,2 Faculty of Economics and Business, Mykolas Romeris University, \\ Ateities str. 20, LT-08303, Vilnius, Lithuania \\ *E-mail: g.kriauciunaite@mruni.eu
}

\begin{abstract}
Purpose - this article aims to analyse and integrate the limitations of consumer's decision-making and difficulties for symbolic consumption in relation to symbolic branding. It highlights the symbolic impact to goods, which influenced by advertising and 21 st century consumer's behaviour propagates hedonistic values.
\end{abstract}

Research methodology - the analysis of theoretical scientific literature, comparative study of conceptions.

Findings - support the idea that consumers may modify their principles about the symbolic brand depending on both their self-brand relation as well as the effect of social (both live and virtual) influence.

Research limitations - it is necessary to acknowledge that the current research is limited by broad scope consumer behaviour theories and methods (we in passing analysed empirical proves).

Practical implications - authors suggest that the emergence of brand subculture on consumer behaviour gives the possibility of adjusting specific marketing strategies and presents the shortcomings of current research by pointing out the trends for future empirical studies.

Originality/Value - It also highlights that the consumers' search of symbolism and meaning in brands correlated with their consumer buying decision models, and we claim it could be related to utility theory. The main aim of this article is to analyse the field of symbols in advertising - in terms of their impact on the consumption process.

Keywords: consumer behaviour, symbols, consumption, marketing strategies, advertising.

JEL Classification: M31, M37, Z13.

Conference topic: Contemporary Issues in Economics Engineering.

\section{Introduction}

Scientific research demonstrates that changes in consumer behaviour are mostly caused by environmental factors and lifestyle changes that affect the choice of goods and services related to consumer expectations as well as their loyalty and their attachment to the producer of it or the brand. The advertising of goods and services is no less important for consumer choice as are various elements of symbols.

Symbolic domination is based on the idea that objects derive symbolic meaning from the social interaction people have with other individuals and organizations in society (or virtually). They are creating social meanings which are shaped in and through the defining actions of a society or culture. There are specific examples of goods charged with specific symbolism in the market: crucifixes, medals, diplomas, or engagement rings. They indicate the commitment to faith, an achievement or a compromise (Zang \& Kim, 2013) in order to demonstrate more pragmatic and explicitly interpreted consumer behavioural patterns, the symbolic approach have started to be developed. Theoretical analysis shows that each model is based on certain spaced variables. Nevertheless, some assumptions are understood as specific forms of social direction and used as symbols.

Presently, we have numerous methods which help us recognizing the decision-making process on different backgrounds of multidisciplinary culture - economics and usually psychology. Researchers propose alternative typological orderings with five main developed methods. Each of these approaches suggests different models of the subject and highlights the necessity to study quite different variables. These models are "economic man", psychodynamic, behaviourist, cognitive and humanistic. In this paper we are not going to analyse all of these. What is more relevant for this research is the new approaches and discoveries in behaviour economics and new methods. 
Although there have been numerous studies analysing consumer behaviour from different angles the question, which one is efficacious, remains. Mostly from an individual and organisational point of view observations were made by Bakanauskas and Vanagiene (2014), Zikiene (2009), Keller and Richey (2006), Moore (2010), Monat (2009), Solomon (2017), Dibb and Nina (2008). There is also the dynamic social-cultural appearance affecting consumer behaviour and was analysed by Stankevičienè (2008), G. E. Belch and M. A. Belch (2004). Social class and culture have been taken into consideration by Banyte and Kazakevičiūtė (2012) who studies the hedonistic approach and its impact on consumer behaviour as well as Nopnukulvised, Husamaldin, and Bowen (2019). One of the most effecting perceived values is constant and comprehensive consumer engagement it originates or increases in brand trust - self-identification with a company or a brand, attitudinal and/or behavioural loyalty. Mollen and Wilson (2010), Perner (2009), O'Connell, Walden, and Pohlmann (2011) studied the psychological aspect of the consumer buying process affecting the moment when a person decides to buy. Some researchers have made some observations about the influence of consumer buying decision from a symbolic positive approach like Tian and Belk (2005). Sirgy et al. (1997), Kressmann et al. (2006) and some of them sees symbolism as a negative phenomenon stating that rejection is essence of anticonsumption and a crucial element to some of the dominant connections in symbolic consumption Hogg, Banister, and Stephenson (2007), Lee et al. (2009), also Fournier (1998). Negative symbolic meaning is acceptable to Ligas and Cotte (1999), Solomon (1983), Muniz and O'Guinn (2001). The symbolism of goods may be understood contrariwise by other researchers' group who analyse different cultures (Shrum et al., 2013), or by precise psychological features (Millan \& Mittal, 2017; Sangkhawasi \& Johri, 2007) also as a use of religious symbols (Stolz \& Usunier, 2018).

Based on and Mullainathan's and Thaler's (2002) research programme of behavioural economics which has added these principles: "the identification of the manner in which behaviour is different from the standard model and pointing out the manner in which this behaviour matters in the economic context". The already mentioned researcher Thaler in 2017 got a Nobel prize for the discovery of anomalies which challenge the traditional paradigm also the development of new, psychology-based models of economic behaviour; advances in helping people to make better decisions; and an influx of talented researchers into this study field (Barberis, 2018).

From company's point of view, to understand and to analyse consumer behaviour patterns helps not only to identify their own marketing strategies or target market but also to apprehend the buyer psychologically, one's expectations and the validity of the decision to buy. From a consumers point of view, it is always something emotional involved in any buying process.

Therefore, despite the various aspects and angles it can be argued that from the classical point of view, consumer behaviour could be defined by the philosophical idea presented by A. Smith as a "rational economical person" who cares only about his own interests, which forms the entirety of decisions - to buy or not to buy certain goods or services, depending on one's ability and desire to demonstrate one's economical capacities to purchase it. In this extent, it is interesting for this research to see the preferences in choosing the specific brand or more precise, the symbolic meaning hidden behind the product also the consumer's choice to be loyal to it often having simultaneous motives.

In this research we are seeking to reveal also a correlation among utility and hedonic method's meaning in symbolic consumption. The purpose of this the research is to analyse theoretical aspects of consumer behaviour elements and its relation to the symbolic buying process tempted by seductive advertising and/or famous brands.

\section{The theoretical background of consumer purchase decision-making process}

Consumer decision-making process has been for a long time the interest of scholars. It is believed that it was started in the $18^{\text {th }}$ century by the economists John von Neumann, Nicholas Bernoulli and Oskar Morgenstern, who initiated to observe the essence of consumer decision making in addition to this started paying attention for the tendencies of human behaviour which affects the buying process (Richarme, 2005).

Most of the authors have the same opinion about the definition of "consumer behaviour" with slightly different approaches, for instance, Solomon (2017) describes this term as "the processes involved when individuals or groups select, purchase, use or dispose of products, services, ideas or experiences to satisfy their needs and desires", while Hawkins and Mothersbaugh (2015) states: "the study of individuals, groups or organizations, and the processes they use to select, secure, use, and dispose of products, services, experiences, or ideas to satisfy needs and the impacts that these processes have on the consumer and society". These opinions reflect the same view, just one focuses on individuals while another one - to the group of buyers.

Stankevičienè describes consumer behaviour as "individual actions related to the purchase of goods and services and relating the deeds of the problems that may arise from the moment of the purchase of goods, the occurrence of the reaction of the already purchased goods and already used product" (Stankevičienè \& Butkute, 2008). According to Bakanauskas and Vanagiene (2014), opinion consumer behaviour "is the consumer's emotional and physical activity related to seeking, purchasing, using, removing and evaluating satisfying (problem-solving) products" (Bakanauskas \& Vanagienè, 2014).

Summarizing all of these definitions it could be shortly said that consumer behaviour is about when, why, how and where people are buying or not. It is also a part of constant research which examines individual habits and their decisions to buy specific goods as well as complaints, the return process, the influence of all internal and external 
factors on consumers, and, finally, the influence of consumer behaviour on the company's goals. Consumer behaviour is also a quite complex field of science requiring good knowledge of marketing, so in order to select the right marketing factors, to formulate precise strategies, it is expedient to carry out an extensive range of studies that would allow a consumer to be better acquainted to predict one's behaviour, and to reveal in which stage of the procurement process one is.

Consumer decision-making models are frequently used in consumer behaviour studies and research areas in order to build a theory. First models of consumer behaviour had one simple main objective that was a systematic and indepth considered buying process (Howard, 2007). Recent times there are many models thus they are discovered to get the information from different approaches, they are still attempting to seek for one goal - to comprehend what occurs in an actual state until a consumer chooses to buy a product or a service. It is necessary to add that some of the bestknown consumer decision-making models have been established since 1960s and 1970s during the time characterized by limited theory on consumer behaviour and when theories from other disciplines were used and of course up to our days we have developed the new ones thus, the pioneers are still used as well.

Looking from the chronological point of view, Walters (1978) states that consumer decision-making models identify the exact reason and effect that relate to consumer behaviour. Engel, Blackwell, and Miniard (1995) continue this idea by explaining that consumer decision-making models offer many advantages such as:

(1) The opportunity to understand what happens as circumstances change;

(2) Giving theoretical structures of orientation that rationally specify the interrelation of variables for research purposes;

(3) Offering the possibility to understand different consumer decision processes and marketing strategies;

(4) Playing an important part in the establishment of theory (Walters, 1978).

Nowadays we are using the consumer behaviour theory as an analytical model most often. Simplification of a consumer gives the understanding of the buyer as a condition. This theory is also an analytical model and it gives a cultured combination of various psychological, social, as well as market impacts on buyers' decision making. It is also necessary to add that in the consumer decision model most of the fundamentals are alike to those in a buyer behaviour model. For instance, the reasoned theory is a narrow model and it is an additional improvement of the "Fishbein model" which projected that a person's whole attitude to an object is consequential to his beliefs and feelings about countless qualities of the items. Planned behaviour theory is an extension of the concept of reasoned action which is established by adding extra changeable intentions and trying to bring an argument to behaviour. The mode focussed to behaviour can be explained as humanistic as it pursues to find concepts thoughtful to the personal consumer rather than describe common processes (Senasinghe \& Peter, 2017).

To put all mentioned models in a nut shell, researchers usually have to pay attention towards consumption behaviour that contains the complexity of emotions, different situations as well as personal effects under precise conditions rather than buyer behaviour as such. Even thought, it is broadly used and published traditional models of consumer behaviour should not be regarded as a norm for organized research and the interpretation of research findings. Despite of many models used in economics which we described before in order to reach the main goal- to understand the human behaviour towards buying process, there are two kinds of cognitive models that are commonly used as well. Analytical models offer a background of the main elements that are supposed to describe the behaviour of consumers and narrow models provide a framework to organize how consumer behaviour is systematized. Looking from a schematic point of view Figure 1 could be visualised as Fishbein and Ajzen:

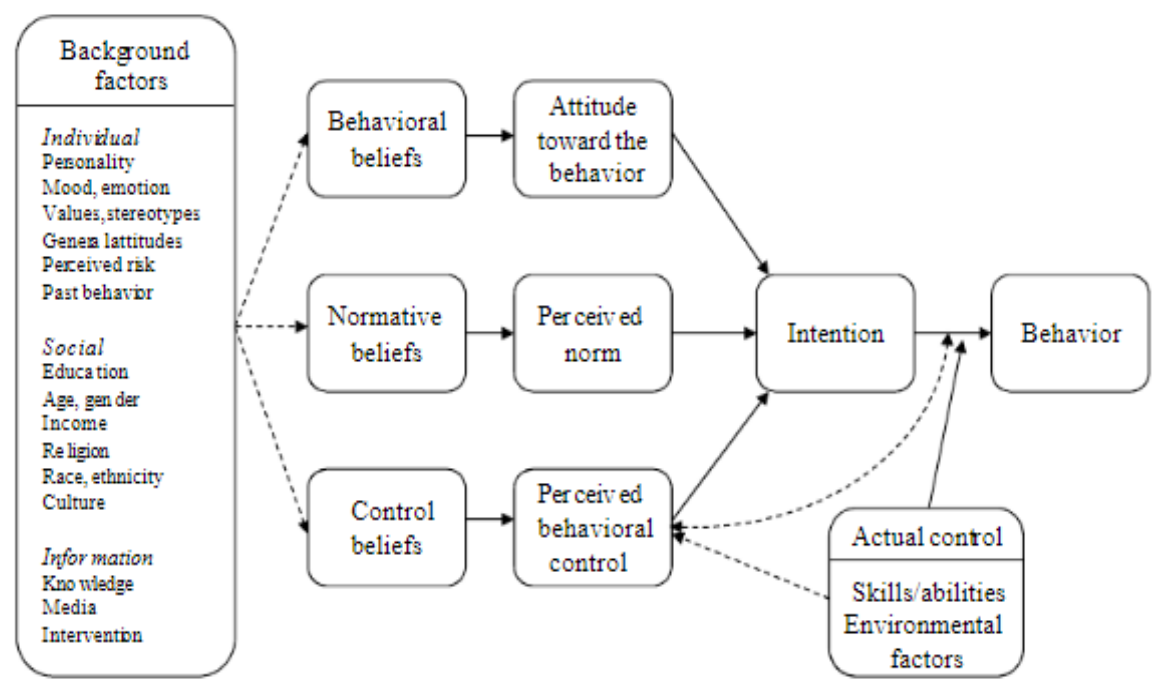

Figure 1. The reasoned Action Model (source: Fishbein \& Ajzen, 2010) 
As demonstrated above subjective norms and behavioural control are shown to be connected to a reinforced of noticeable behavioural or forced beliefs about the behaviour (Fishbein \& Ajzen, 2010). It helps to gain an understanding about the hidden cognitive basis and to explain specific attitudes, subjective standards, and insights of behavioural habits (Fishbein \& Ajzen, 2010). Finally, several fundamental elements effects behavioural, normative, and control beliefs. As a result, such background factors influence attitude, subjective norm, and perceived behavioural control.

Grand models to attendee's behaviour and five stages of decision-making acceptance also demonstrates a wide variety of factors which affects the consumer and consumer behaviour reflections besides that recognises broad range activities beyond the buying process. According to Mair and Thomson (2009), all the main models which have been established to clarify buying process, have five main stages: information search, motivation, evaluation of alternatives, decision and post-decision behaviour (Mair \& Thompson, 2009).

Among all the grand models which have been developed to explain decision-making process especially choosing symbolic goods or brands, there are five common stages: motivation, information search, evaluation of alternatives, decision and post-decision behaviour. The consumer behaviour literature has explored various concepts related to information search and its implications for marketers since the kind of search consumers undertake has significant implications for the kind of purchases they eventually make.

In consumer behaviour theory there are many models which we have shortly presented nevertheless, we would like to present the one, which is rarely mentioned in scientific literature and more related to our research interest about choosing the symbolic brands or goods with symbolic meaning and one of our hypothesis could be - the stimulus of utility or hedonic intentions affected by postmodern life (to new generation) demands of constant inner fulfilment.

Some scientists have analysed human behaviour in a quite rigid method (pure rational) or from only economic observation (standard economics), mostly not paying attention to take into psychological structures in their studies. Study firstly made by Kahneman and Tversky (1979) have revealed that consumers are not always pragmatic in their choices and other later took the pattern from them. In this perspective came utility model, which exposed major faults, such as by Simon defined the conception of "satisficing" according to which the individuals' rational choices are restricted to cognitive and emotional capacities (Simon, 1972). Since we are focusing on symbolic consumption the most relevant model to our research theme would be this utility theory. This theory gives a hypothetical assumption for studying the decision-making process under vague conditions; based on this theory, personalities choose the result that improves their welfare (Foxall, 2016).

As the table above demonstrates, a buyer is affected by cultural, social, personal and psychological aspects in decision-making process for consumers. Every factor can be divided into forthcoming subgroups that help regulate how and why consumers make their choices.

Despite of characteristics influencing consumer behaviour utilitarian values which craves for effective, coherent, task-oriented attempt relevant process of buying products, therefore, it is not even related to cultural or social etc. values (Babin, Darden, \& Griffin, 1994). The different types of interests among buyers suggest that within most product categories, consumers' needs could be either functional or symbolic in their nature as for more, brands assigned to please either of these two types of needs. Thus, functional or utilitarian needs of consumers could be exploited with a "functional" brand, for instance, one positioned with a functional brand concept or meaning. Similarly, a brand could be positioned as a "symbolic" brand to tap the needs of those who wish to enhance their self-image or their social image.

Consumers motivated by utilitarian values with the help of online shopping may seek the convenience of saving time or the simply way of accessing information (Anderson, Knight, Pookulangara, \& Josiam (2014); Belk, (2016); Stephen, (2016)). For consumers motivated by hedonic values, the experience itself is important (Babin et al., 1994). These consumers enjoy the experience without the need to make a purchase, but a purchase is a result of the experience. Hedonic values can include a desire for entertainment and distraction or the wish to find a good deal and the enjoyment of the hunt for a good bargain (Babin et al., 1994). The motivation positively influences consumers' attitude towards online shopping (Terry, Childers, Carr \& Peck, 2001) and virtual shopping technology (Kim \& Forsythe, 2007). Hedonic values also positively influence consumers' attitude towards social network advertising (Anderson et al., 2014) and social networking by projecting their living as partly their identity, which refers to their goods (Stephen, 2016). Some studies emphasize the consumption of experiences process, which can be defined as the consumption of sensations and memories in an environment able to create them (Gazley \& Waitling, 2015). For Servidio (2015) current consumers' motivations and needs become complex, and they demand feeling, symbolic meanings and memories to be shared between the experience and themselves nevertheless, it leads for seeking the utilitarian values.

Hedonic consumer behaviour and utilitarian consumer behaviour is a result of attitudes, motives and values it might be evidence to purchase and consumption behaviour. Scientific analyses on consumer behaviour propose that consumer buying goods and services and perform consumption behaviour because of the two basic reasons: hedonic satisfaction (from sensory attributes); utilitarian reasons concerned (from functional and nonsensory attributes) (Teller, Reutterer, \& Schnedlitz, 2008; Millan \& Howard, 2007). Both the utilitarian and hedonic aspects have two sides. Hedonic features contain pleasant feelings as well as unpleasant, at the same time utilitarian features include judgements about illogicality as well as logical, functional and product-centric thinking (Rintamaki, Kanto, Kuusela, \& Spence, 2006). Hedonic value is connected with satisfaction, experiences of pleasure, fun, entertainment or fantasy 
(Babin et al., 1994). Utilitarian value can be characterized as necessity fulfilment. The term hedonism is usually associated with a negative meaning related to immediate satisfaction, extreme personal selfishness and materialism (Szmigin \& Carrigan, 2006). In today's society we refer "hedonistic" as a synonym to individualistic or a person who seeks a "good life". The "good life" means a person's dissatisfaction with consumerism and materialism in a tendency to choose alternative forms of consumption practices.

It is believed that products as symbols within society are central to postmodernism and technology wave, although we are not going to the direction as was promoted by Stankevičienè or Bakanauskas, who claimed that consumer behaviour for satisfying needs and deeds, but rather agree with Solomon (2017) also Gazley and Waitling (2015) or Servidio (2015), who state that consumerism is an involving process which leads to satisfaction (symbolic meanings and memories own experiences and personal history).

The statement, which we are going to discuss in the following chapter declares that a consumer does not make one's choices based on a product's utilities, but on its symbolic value; we will also cover the role of symbols in the consumer decision-making process. In consumer behaviour theory all the described grand models such as our mentioned analytical model, Fishbein model or planned behaviour theory are just a few examples which we presented and all of these theories we could emphasise that they develop into our focus - utility or hedonic model with symbolic affirmation. Since the approach to symbolic consumption behaviour as a marketing concept consider the striving for social recognition and status seeking ("brand personality") or consider the desire to signal either group conformity (in sociality or in social networking) or the idea of the motive of complying with one's self-image and supporting one's self-esteem (consumerism as a help).

\section{Consumption versus consumerism and the role of symbols}

Scientific studies confirm that such terms as "consumer society" or just "consumer culture" became famous by such authors as Marcuse, Baudrillard, Packard and others. They contend that capitalism has transformed the world into a society of consumerism. These authors see some ambiguity in the term "consumerism", which one supposes to express censorship rather than an explanation. Usually, this term does not offer a decent understanding of what is going on in society but this meaning rather stigmatizes the growing and uncontrolled passion for goods (Sassatelli, 2007). According to Twichell (1999), the word "consume" sounds scary, it means to "ingest, use up totally".

Therefore, we need to distinguish between consumerism and consumption, because "consumption" is the act of consuming (eating and using) material goods to sustain and enjoy life. Meanwhile, consumerism makes consumption the ultimate goal of life, either explicitly or implicitly (Abela, 2007).

Consumerism is much related to a person's well-being as the same goes for consumers. People who have low self-esteem tend to spend more money and have a tendency towards depression and low ethical standards. This phenomenon marked the beginning of spiritual pauperization, in which human beings are persuaded, for convenience sake, to desire material goods, a surrogate for traditional forms of pleasure, self-realization and identification through work and political participation (Sassatelli, 2007).

Consumerism, these days, is blamed for everything and has become the primary hotspot of modern culture. It has been accused of the rise of eating disorders, the spread of affluenza, the epidemic of depression, the destruction of cultural icons, the corruption of politics and the carnivalization of holy celebrations like Christmas, and even more for the attention span of our youth (not only Christmas is a fiesta of gifts, but we have even more special days for buying goods, as Valentine's Day, Mother's Day, Father's Day etc...). Certainly, we cannot agree with all of these contenders. In other words, commercialism is more a mirror than a lamp. Another quite positive effect we could mention is that consumerism creates some rituals, such as those in a community, a family, a personality and a state itself. According to this subdivision, we have to take into account that this access to material life happens via advertising, branding and packing (Twitchell, 1999).

A huge impact for consumerism is established through celebrities, stars created by the media, even computer game heroes, with perfect bodies, things or different kinds of entertainment trying to seduce us and to present life as having more goods (even perfect) things as a goal of life. It has become important not because of natural survival but more for psychological comfort; happiness, popularity - just a part of the aims of consumer society (Kasser, 2002).

Buyers gather sensations not just to feel good. The main idea of goods is to possess things for pleasure. Twitchell argues that we satisfy our desires in shops, and not our needs, and we are doing it just in that order of satisfaction (Twitchell, 2009). Furthermore, reflection of consumers' identification of different behavioural patterns creates a new method (Ranaweera, McDougall, \& Bansal, 2005) allows in real time to catch the moment by (video) recording, which is the best way to capture the process and recognize decision-making forms, which was done by Karimi \& Papamichail (2015).

We live surrounded by things, for things, we exchange things, in our culture we buy things, steal things, and hoard them. This process is a huge force not just for economics in general but also for a certain kind of people, who find their fulfilment in the buying process and in the unpacking procedure of new goods. Kasser elaborates on this argument by stating that the reason why materialism is concerned with happiness just because materialism focuses on the human soul. The desire to possess more and more pushes people into a crazy step in life. Kasser observes that: "not only must we work harder, but once possessing the goods, we have to maintain, upgrade, replace, insure, and constantly 
manage them" (Kasser, 2002). It seems that in this situation a person replaces his inner emptiness or lack of spirituality but the worst of it is that goods (or consumerism in general) propose happiness, yet in reality they create another empty hole along with stress, anxiety and lack of love, therefore, it gives a symbolic value for existential as so. The main question is why the symbols we see in the process of buying and also in the goods force us not just to survive but also to feel satisfaction? And actually, we are still raising the question what do we need from the shops and what we are pursuing there?

The concept of symbolic consumption is understood in the context of consumer behaviour. Marketers can improve symbolic importance with the help of consideration to the countless elements of the marketing strategy. There is an acknowledged fact that consumers may buy a product for a specific reason and it is other than the product's basic functional performance (branding). Consumers are often motivated to purchase a good or a service on the basis of what it represents to themselves and to others with whom they associate or to some societal referent. Usually, individuals are assumed to relate to objects or events based on their symbolic meaning given by society.

Symbolic consumption is the process of buying goods or services which customers believe will create, approve, or pass on their own unique identities (Bhat \& Reddy, 1998). Some researchers state that symbolic consumption could be definite as the attention on the concept that consumers' identities can be articulated via the variety of brands which bear specific symbolic messages via the internet (Belk, 2016). Without a doubt, most of the brand's accomplishment is the result of its symbolic meanings which is portrayed via brand consumption. Thus a brand is a symbolic source to be used by the customer to establish lifestyle, self-concept or even a social status (Bhattacharya \& Sen, 2003).

The issue has been researched in some complexity within the literature, across a range of contexts. Han, Nguyen, and Simkin (2016) have checked many brands from various spheres, remarking that the status of symbolic consumption lies in its capacity to fit various symbolic requirements of the consumer. Kim and Jang (2014) agree, proposing that for young consumers using expensive brands, the symbolic feature of consumption is an important motivating factor. Many noticeable products are becoming gradually subtle concerning their symbolic meaning, it seems that (especially younger) people tend to accept noticeable products as a symbolic necessity which can carry an image of their preferred dream lifestyles (Kim \& Jang, 2014).

Consumer researchers have studied goods just to understand consumers and symbolic consumption, while the advertising industry studies products to understand what kind of sense products have to consumers. There are researchers who consider goods as social symbols. Social psychologists have studied products as symbols of self-completion. Marketers have studied product images in order to raise sales, for this reason, it is important to make clear about the role of symbols in the consumer's purchasing process.

Companies often struggle in order to understand the consumers' buying behaviour better, they also engage in advertising and promotion activities to impact the consumers' purchasing decision. However, when they are engaging in such types of activities, they need to take into account other external aspects such as the inclusive economic conditions of the country, technology culture, politics - everything beyond the control of both the consumer also company (Lancaster \& Reynolds, 2005).

Advertising has an astonishing tool to play (games) with our emotions, feelings, belief-systems and symbols. In order to understand how it influences us and our society. There are a lot of discussions about the meaning of symbols used in all parts of the world in different moments of life. We can call it a symptom of something deeper, meaningful, sacral, negative and positive at the same time. One of the reasons which increase the conflicts related to symbolism is that we confuse the language (meaning and our understanding of it) used in philosophy, sociology and in marketing as well.

Defining symbols and symbolism in general, as was introduced in this section, becomes more difficult when mixing them with signs (Baudrillard \& Levin, 1981). On one hand, symbols are the ownership of human beings, although, they can have meaning in themselves, they represent one's existence. By Dupré (2000), "Symbols usually introduce the double meaning: present something and take the place of it". Therefore, they both (symbols and signs) are responsible in the same way but they have different meanings. Thy both refer to something more meaningful beyond themselves. The most common example of a sign could be a red light at a crossroads: it does not refer to itself, but requires the necessity to stop the car. The same goes for a symbol participating in life - it means more than reality itself. Tillich emphasizes that the main difference between this participation beyond is that "signs do not participate in any way in the reality and power of that which they point to." (Tilich \& Kimball, 2015). On the other hand, symbols usually are not the same as they symbolize in the meaning of their participation and power. For example, in all languages we can find a letter which does not share the sound which it refers to. A much better example of a symbol's participation is the meaning of a flag. It demonstrates not just a piece of material but the essence of it is to show the power of a monarchy or a nation for which it stands and, of course, which it symbolizes (Tilich \& Kimball, 2015). Dupré gives an argument for that: "All symbols reveal a reality beyond their sensuous appearance. A common interpretation restricts the "reality" of this definition to what precedes the symbolization precedes it (Dupré, 2000).

The most common misunderstanding in using symbols becomes ambivalent between appearance and content. The symbol manifests the internal opposition of the mind which it expresses. The fundamental function of the symbol is to enable this mind to express itself. A symbol always appears as containing a surplus of meaning beyond what it directly discloses and the best participation of a symbol could be found in the consumer buying process and it affects their buying decision-making process. 
According to the Canadian journalist and columnist and, at present, one of the famous social writers on a topic of branding and advertising Naomi Klein, "branding is about a global lexicon of imagery, music and icons" (Klein, 2010) and in this fashion, it transfuses a code into our brains. Branding, as a new member of the community - even leadership with companies such as Nike, Benetton, and Starbuck's which have built their brands on meanings such as transcendence, multiculturalism and belonging, respectively, puts spirituality into the market, which offers a permanent, bounded identity, in which you are told about your real self. It suggests an invitation to endless confidence. It promises a new life (Beaudoin, 2007). It can even be seen as derived from Western spiritual disciplines. It proves that "economy as a discipline is not consciously "spiritual" or "religious", but it operates with a dynamic similar to classical spiritual disciplines - anonymously" (Beaudoin, 2007). We will see the deliberate use of this by companies.

The brand is not just a name of a company or a product. It represents even more: a myth, a symbol that serves emotional meaning. It is influenced by many aspects, on the one hand, in the case of creating and formulating a brand. In reference to brands, companies raise many questions such as: what is the historical background of the company and country in which the product should be launched? Are there any national or regional thought? What is the brand gender? Does the packaging or presentation reflect the "norms" of the market? What kind of message, symbol or value does the brand represent? Brands consistent in their promises, images, identity, quality and advertising here is the most important component. When a strong brand changes, keeps up with the pace and develop, generate awareness, does it have the ability to create brand preference? As mentioned, brands have to adjust in order to satisfy individual responses and needs (Beaudoin, 2007).

Diminishing thought has taken into account that consumers are emotional beings especially in regard to how they subvert the rationality of action in different ways. For instance: through belief formation - as wishful thinking, through information acquisition jumping to conclusions; and through (most importantly) the lack of regard or neglect of thought about consequences - such as lack of concern for more information (Beaudoin, 2007).

Historically, when marketers speak about brands, they refer to the product itself in terms of quality, price and, of course, function. Nowadays it is not enough to sell a product or a service as a meaning should be behind the product otherwise, no attention will be paid to it. "The fact is great brands have personalities; they have attitude and they give greater depth and meaning to that product" (Gobé, 2002), the surroundings, type of advertising or, promotions seen around it. Is it brightly red Coca-Cola, a McDonald's cheese-burger or maybe a cup of Starbuck's coffee? Hence the question raised is what kind of lifestyles are we admiring behind or beyond our surrounded brands reflect our daily life and our personalities, what kind of values and ideals are they creating on us (Gobé, 2002).

It could be presumed, that the branding culture has replaced the religion and could be referred with Marx famous citation "opium of the people". It becomes "a form of alienation; a symptom of social malformation which distinguishes the exploitative forms of capitalist society" (Davie, 2007). Scholars convey their cynicism of religion as a tool to persuade and affirm the dominant worldview. They state that the market as the new religious group brand critical and dominant members of society not just with a new name, but with new inspirations, ideas and theology as well (Davie, 2007). As an example, especially at this time- Apple and Harley, these companies have been successful declared as "Brands are symbols", today the economy is not a formal economy in which products are made to compete in rational terms - it is a "spiritual" and "symbolic economy" in which what is sold is "community", meaning, and shared experiences. Rather than reducing religious phenomena to economic terminology. Far from portraying consumers as rational actors seeking to maximize utility, let alone applying this rationale to religious "consumers", looking at the evolution of marketing is instructive as to how consumerism actually works (Atkin, 2004).

Many scholars claim that the nature of branding is the promise within the mind of the consumer (Pringle $\&$ Thompson, 1999). Brand "identity" elements (the promise) usually target all of us which are the reason why we buy one product rather than another. What is the message we perceive before we choose? What are companies thinking before creating a brand? What are the main ideas for them? The answers could be found in brand messages, for instance from the lens of marketers Coca-Cola and Pepsi are selling the idea of youthfulness, friendship; Kodak is not selling just cameras; it sells memorable moments, Apple is not just computers and phones - they are selling the ability to be fashionable (by knowing the new technologies), Rolex it is not just a watch - it is a status and many other emotionally or rationally taken decisions to buy. The branding approach is based on creating a unique and symbolic psychological association and identification between the brand and the consumer. Here, the brand differentiation comes from the brand trying to occupy the unique "personality" and "lifestyle" imagery and associations that their target audiences identify with and aspire for (Tiwari \& Rajendra, 2012).

In symbolic consumption, the most important thing is not a quality of the brand but more the recognition and the message it delivers to the buyers. For example, it is not hard to see the quick example of the coffee shop context, our times generation (scientists name it as Generation Y (millennials) or Z) understands visiting brands of a coffee shop (despite the quality of the coffee) as a way of self-expression and a way to communicate their self-identity (Tangsupwattana \& Liu 2018). For example, it can make you feel special like "big city" inhabitant or like a movie star (Kim \& Jang, 2014) even commercial creators use this attribute in order to seduce the consumer to feel special just by drinking ordinary coffee.

Self-concept and consumer lifestyle express the consumer's self-identity and consumption values, these are what we must adopt to capture the holistic image of the symbolic consumption of any product, for instance known clothing 
company United Colours of Benetton had the whole campaign of adverts the main object of which was not a single item of clothing but the social issues such as gender equality, racism, war etc. (see Figure 3). It becomes easy to understand the hint of symbolic consumption when the concept of extended self is taken into account. Genuine selfconcept is a method when people observe themselves imagining an ideal person. It is clear that from this extent, advertising companies and marketing specialists are not just using adverts and symbols in order to sell a specific product or service, they have to bring the message to the individuals that they would feel better as persons when they purchase a specific good. Referring to figures 1 and 2, the company Nike is not just selling sports apparel or shoes; they are selling the idea that by purchasing a person would be able to do anything and would feel invincible despite one's different abilities.

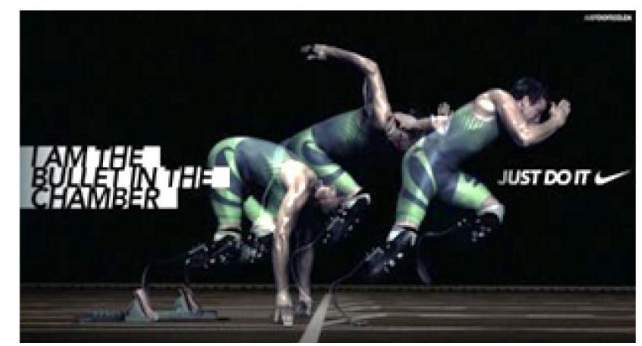

Figure 1. Advertisement of Nike, I am the bullet in the chamber
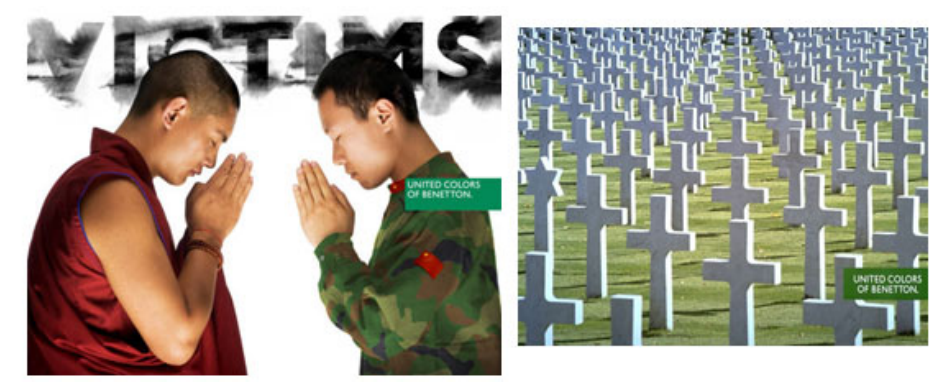

Figure 3. Advertisements of United Colors of Benetton, victims and crosses

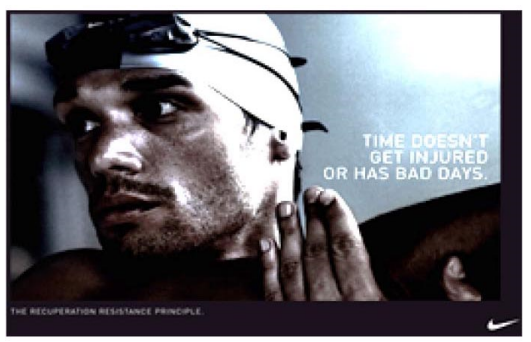

Figure 2. Advertisement of Nike, time doesn't get injured or has bad days

At the same time, the company which sells vodka Absolut has a whole campaign of adverts where they are selling the "better world's idea" despite the ironic fact that the adverts and images they are promoting are the symbols which demonstrate that it is not just alcohol it is the concept of ourselves in front of the world. No need to add that there are a lot of other products such as all ecological or "green" products protecting rights of animals etc. which also sell the idea and symbol of better us (when we buy a specific thing, for example, a product of the Body Shop).

Concluding, as we assume consumerism is a symbolic economy and some of the consumer's a meaning in their life. Products refer to brands which are symbols inscribed in social relations. The hedonistic approach leads to the idea that brand as a cult would be interesting to investigate with its emotional power, such that it can become the touch for belonging, identification, community, individual and cooperative emotion with its rituals, like Stolz and Usunier (2018) defined as "brand religion".

\section{Conclusions}

Economics, as one of the most important domains of our society, has a constant vibrant nature. The attempt to illuminate how one of its side - consumer behaviour methods are functioning and seek explanations for economic progressions - helps to guarantee a good living standard and search for new methods in order to define the consumer's nature and create new strategies for the future marketers.

In this research the review of the consumer's behaviour decision-making models has been undertaken as for more, to emphasize the intricacy of consumer choices and identify the main methods that bring to behaviour. An inclusive variety of models have been posited through the models, and all of them have a suggestion to defend its attempts to explain consumer's behaviour. It is not easy to include all the considerations and factors that influence a consumer choice, however the abstract symbolic consumer behaviour model projected and adopted by this research has reflected upon the work falling into the interdisciplinary approach in an attempt to provide a holistic view of the decision-making process, which for the future research requires collection of data and assumptions by a group of symbolic buyers.

Despite the significant attention that researchers (Lee, Motion, \& Conroy, 2009; Fournier, 1998; Ligas \& Cotte, 1999; Solomon, 1983; Muniz \& O’Guinn, 2001; Shrum et al., 2013; Lerman \& Maxwell, 2006; Sangkhawasi \& Johri, 
2007; Charanya, Laden, \& Gordon, 2019) have devoted to symbolic images, a lot of questions still remain open. One of such questions is how symbolic images become relevant to a consumer despite the acknowledged fact about the human hedonic nature and the need to satisfy one's desires. Thus, some studies (experience consumption is one of the terms) could fit to our topic with the empirical evidence collected by Luna-Cortés (2018). In this empirical context, this scientist is defining the hypothesis that Internet and digital social networks present an ideal opportunity for consumers to show the methods that emphasize their identities as well symbolic in it.

Furthermore, the results of empirical research show that, when consumers desire to materialize their experience, they use virtual social networks. It is indicated as well that higher social value and satisfaction increases the intensity of the use of social sites. Based on the results, some managerial guidelines are included.

Various conceptualizations of relevance have been used, poorly found studies which comprehensively investigated and applied a theoretical aspect of relevance to symbolic visuals in advertising (online or not). This research addresses a need for understanding how relevance occurs through symbolic visuals within the consumer buying process from companies' point of view without event promoting their product but just selling the specific image for a target group of customers.

In the context of globalization, neither the study of consumption, nor the study of consumer buying behaviour, can be explained as the mere interaction between a limited number of personal and impersonal (or external factors), but as an utterly complex and undoubtedly progressive process. Moreover, what today is openly referred to as consumer behaviour research, represents the result of interweaving various and prolonged reports coming from a wide-spanning array of heterogeneous disciplines. Analysing consumers and their purchase decisions/ consumption patterns/ postconsumption attitudes etc. only from an economic or psychological perspective will lead to an over-constrained problem, for which the solution will be at the same time academically unsound, and practically infeasible.

Even though this research represents a theoretical inquiry of literature, exhaustiveness is not one of its goals. Moreover, whilst they present evidence coming from previous works, the authors do not shy away from stating their own beliefs and ideas, thus imbuing the present work with an unmistakable subjective perspective. Research instruments to investigate consumers, for there are subsequent disciplines that contributed to the rise of this held of inquiry for future research empirical evidence for consumer behaviour and its effect on the symbolic consumption.

\section{Reference}

Abela, A.V. (2007). The price of freedom: consumerism and liberty in secular research and catholic teaching. Journal of Markets and Morality, Spring, 10(1), 17-28. Retrieved from https://www.marketsandmorality.com/index.php/mandm/article/view/260

Atkin, D. (2004). The culting of brands: when customers become true believers. New York: Portfolio.

Anderson, K. C., Knight, D. K., Pookulangara, S., \& Josiam, B. (2014). Influence of hedonic and utilitarian motivations on retailer loyalty and purchase intention: a Facebook perspective. Journal of Retailing and Consumer Services, 21, 773-779. https://doi.org/10.1016/j.jretconser.2014.05.007

Babin, B. J., Darden, W. R., \& Griffin, M. (1994). Work and/or fun: measuring hedonic and utilitarian shopping values. Journal of Consumer Research, 20(4), 644-656. Retrieved from https://www.jstor.org/stable/2489765

Bakanauskas, A., \& Vanagiene, V. (2014). Naujo prekès ženklo stiprių asociacijų pirkejjui sukūrimas, pozicionuojant naujo maisto produkto vertę. Management Theory and Studies for Rural Business and Infrastructure Development, 2, ISSN 1822 - 6760, 197-206. Retrieved from mts.asu.lt/mtsrbid/article/download/813/837

Banytė, J. \& Kazakevičiūtė A. (2012). The relationship of consumers' perceived hedonic value and behavior. Engineering Economics, 23(5), 532-540.

Barberis, N. (2018). The rise of behavioural economics. Scandinavian Journal of Economics, 120(3), 661-684. https://doi.org/10.1111/sjoe.12313

Baudrillard, J., \& Levin, C. (1981). For a critique of the political economy of the sign. Telos Press.

Belch, G. E., \& Belch, M. A. (2004). Introduction to advertising and promotion ( th $^{\text {th }}$ ). New York: McGraw Hill. Retrieved from https://acrwebsite.org/volumes/6260/volumes/v11/NA-11

Belk, R. (2016). Extended self and the digital world. Current Opinion in Psychology, 10, 50-54. https://doi.org/10.1016/j.copsyc.2015.11.003

Beaudoin, T. (2007). Consuming faith - integrating who we are whith what we buy. Rowman \& Littlefield.

Bhat, S., \& Reddy, S. K. (1998). Symbolic and functional positioning of brands. Journal of Consumer Marketing, 15(1), 32-43. https://www.emeraldinsight.com/doi/abs/10.1108/07363769810202664

Bhattacharya, C. B., \& Sen, S. (2003). Consumer - company identification: a framework for understanding consumers' relationships with companies. Journal of Marketing, 67(2), 76-88. https://www.jstor.org/stable/30040524

Nopnukulvised, C., Husamaldin, L., \& Bowen, G. (2019). The differences of hedonic shopping value and purchase intention in the multichannel shopping environment for apparel shoppin. Leveraging Computer-Mediated Marketing Environments. London, UK. https://doi.org/10.4018/978-1-5225-7344-9

Davie, G. (2007). The sociology of religion. Los Angeles, CA: Sage.

Dibb, S., \& Nina M. (2008). Consumer involvement: a new perspective. Marketing Review, 8(1), 83-99. https://doi.org/10.1362/146934708X290403

Dupré, T. L. K (2000). Symbols of the sacred. Grand Rapids, MI: Eerdmans. 
Engel, J., Blackwell, R. D, \& Miniard, P. W. (1995). Consumer behaviour. International ed. Florida: Dryden.

Fishbein, M., \& Ajzen, I. (2010). Predicting and changing behavior: The reasoned action approach. NY: Psychology Press.

Fournier, S. (1998). Consumer resistance: societal motivations, manifestations and implications in the consumer behavior domain. Advances in Consumer Research, 25, 88-90. http://acrwebsite.org/volumes/8130/volumes/v25/NA-25

Foxall, G. R. (2016). Operant behavioural economics. Managerial and Decision Economics, 37, 215-223. https://doi.org/10.1002/mde.2712

Gobé, M. (2002). Citizen Brand: 10 Commandments for transforming brand culture in a consumer democracy. New York: Allworth.

Gazley, A., \& Waitling, L. (2015). Me, my tourist-self, and I: The symbolic consumption of travel. Journal of Travel and Tourism Marketing, 32(6), 1-17. https://doi.org/10.1080/10548408.2014.954690

Han, S. H, Nguyen, B., \& Simkin, L. (2016). The dynamic models of consumers' symbolic needs: in the context of restaurant brands. European Journal of Marketing, 50, 7/8, 1348-1376. https://doi.org/10.1108/EJM-03-2015-0144

Hawkins, D. I., \& Mothersbaugh, D. L. (2015). Consumer behaviour: building marketing strategy (13th ed.). Boston: Irwin/McGraw-Hill.

Hogg, M. K., Banister, E. N., \& Stephenson C. A. (2009). Mapping symbolic (anti-) consumption. Journal of Business Research, CA, 62(2), 148-159. https://doi.org/10.1016/j.jbusres.2008.01.022

Karimi, S., \& Papamichail, K. N. (2015). The effect of prior knowledge and decision-making style on the online purchase decisionmaking process: A typology of consumer shopping behaviour. CP Holland, Decision Support Systems, 77, 137-147.

Kahneman, D.A \& Tversky, A. N. (1979). Prospect theory: an analysis of decision under risk. Econometrica, 47(2), $263-291$. https://doi.org/10.2307/1914185

Kasser, T. (2002). The high price of materialism. Cambridge MA: MIT press. https://doi.org/10.7551/mitpress/3501.001.0001

Kim, D., \& Jang, S. (2014). Symbolic consumption in upscale cafés examining Korean Gen Y consumers' materialism, conformity, conspicuous tendencies, and functional qualities. Journal of Hospitality \& Tourism Research, 41(2), 154-179. https://doi.org/10.1177/1096348014525633

Kim, J., \& Forsythe, S. (2007). Hedonic usage of product virtualization technologies in online apparel shopping. International Journal of Retail \& Distribution Management, 35(6), 502-514. https://doi.org/10.1108/09590550710750368

Klein, N. (2010). No logo: taking aim at the brand bullies. Vintage: Picado.

Keller, K., \& Richey, K. (2006). The importance of corporate brand personality traits to a successful 21 st century business. Journal of Brand Management, 14, 74 -81. https://doi.org/10.1057/palgrave.bm.2550055

Kressmann, F., Sirgy, M. J., Herrman A., Huber, F., Huber, S., \& Lee, D. J. (2006). Direct and indirect effects of self-image congruence on brand loyalty. Journal of Business Research, 59, 955-964. https://doi.org/10.1016/j.jbusres.2006.06.001

Lancaster, G., \& Reynolds, P. (2005). Management of marketing, Elsevier Butterworth-Heinemann Linacre House, Jordan Hill, Burlington.

Lee, M. S. W, Motion, J., \& Conroy, D. (2009). Anti-consumption and brand avoidance. Journal of Business Research, 62, 169180. https://doi.org/10.1016/j.jbusres.2008.01.024

Lerman, D. B., \& Maxwell, S. (2006). Joining a consumer society: Russian immigrant versus American materialism. Journal of Consumer Behaviour, 5, 479-490. https://doi.org/10.1002/cb.197

Ligas, M., \& Cotte, J. (1999). The process of negotiating brand meaning: a symbolic interactionist perspective. Advances in Consumer Research, 26, 609-614. http://acrwebsite.org/volumes/8329/volumes/v26/NA-26

Luna-Cortés, L. (2018). The influence of symbolic consumption on experience value and the use of virtual social networks. Spanish Journal of Marketing-ESIC, 21(1), 39-51. https://doi.org/10.1016/j.sjme.2016.12.005

Mair, J., \& Thomson, K. (2009). The UK association conference attendance decision-making process. Tourism Management, 30 , 400-409. https://doi.org/10.1016/j.tourman.2008.08.002

Mollen, A., \& Wilson, H. (2010). Engagement, telepresence and interactivity in online consumer experience: Reconciling scholastic and managerial perspectives. Journal of business research, 63(9-10), 919-925. https://doi.org/10.1016/j.jbusres.2009.05.014

Monat, J. P. (2009). Why customers buy - a look at how industrial customers make purchase decisions. Marketing Research, 21, 20-24. https://doi.org/10.1108/02634501111117610

Moore, K. (2010). The tourist as a metaphor of the social world. CABI Publishing, Wallingford, Oxon.

Millan, E., \& Mittal, B. (2017). Consumer preference for status symbolism of clothing: the case of the Czech Republic. Psychology and Marketing, 34(3), 309-322. https://doi.org/10.1002/mar.20990

Millan, E. S., Howard, E. (2007). Shopping for pleasure? Shopping experiences of Hungarian consumers. International Journal of Retail \& Distribution Management, 35(6), 474-487.

Mullainathan, S., \& Thaler, R. (2002). Behavioural economics. Washington, DC: National Bureau of Economic Research.

Muniz, A. M., \& O’Guinn, T. C. (2001). Brand community. Journal of Consumer Research, 27(4), 412-432. https://doi.org/10.1086/319618

Charanya, N., Laden, H., \& Gordon, B. (2019). The differences of hedonic shopping value and purchase intention in the multichannel shopping environment for apparel shopping. Advances in Marketing, Customer Relationship Management, and E-Services. Leveraging Computer-Mediated Marketing Environments, 125-142. https://doi.org/10.4018/978-1-5225-7344-9.ch006 
O‘Connell, B., Walden, S., \& Pohlmann, A. (2011). Marketing and neuroscience: what drives customer decisions? USA: American Marketing Association. Retrieved from http://www.jointheama.com/newmember/white-papers/White\%20Paper\%20 Neuroscience $\% 20$ what $\% 20$ drives $\% 20$ cust $\% 20$ descisions.pdf

Perner, L. (2009). Consumer price response. Department of Marketing Marshall School of Business Los Angela's, USA.

Pringle, H., \& Thompson, M. (1999). Brand spirit: how cause related marketing builds brands. Chichester: John Wiley \& Sons.

Ranaweera, C., McDougall, G., \& Bansal, H. (2005). A model of online customer behavior during the initial transaction: moderating effects of customer characteristics. Marketing Theory, 5, 51-74. https://doi.org/10.1177/1470593105049601

Richarme, M. (2005). Consumer decision - making models, strategies, and theories, oh my! Retrieved from www.decisionanalyst. com/ Downloads/ConsumerDecisionMaking.html

Rintamaki, T., Kanto, A., Kuusela, H., \& Spence, M. T. (2006). Decomposing the value of department store shopping into utilitarian, hedonic and social dimensions: evidence from Finland. International Journal of Retail \& Distribution Management, 34(1), 624. https://doi.org/10.1108/09590550610642792

Sassatelli, R. (2007). Consumer culture: history, theory and politics. Los Angeles, CA: Sage.

Sangkhawasi, T., \& Johri, M. (2007). Impact of status brand strategy on materialism in Thailand. Journal of Consumer Marketing, 24(5), 275-282. https://doi.org/10.1108/07363760710773094

Shrum, L. J., Wong, N., Arif, F., Chugani, S. K., Gunz, A., \& Lowrey, T. M., et al. (2013). Reconceptualising materialism as identity goal pursuits: Functions, processes and consequences. Journal of Business Research, 66(8), 1179-1185. https://doi.org/10.1016/j.jbusres.2012.08.010

Senasinghe, V., \& Peter, S. (2017). Consumer behaviour models and microfinance in Sri Lanka: A systematic review of literature. International Research Symposium on Pure and Applied Sciences. Sri Lanka: Faculty of Science, University of Kelaniya. Retrieved from http://repository.kln.ac.lk/handle/123456789/18218

Servidio, R. (2015). Images, affective evaluation and personality traits in tourist behaviour: An exploratory study with Italian postcards. Tourism Management Perspectives, 16, 237-246. https://doi.org/10.1016/j.tmp.2015.08.003

Simon, H. (1997). Administrative behavior: a study of decision-making processes in administrative organizations (4th ed.). New York (N.Y.): The Free Press.

Solomon, M. R. (1983). The role of products as social stimuli: a symbolic interactionism perspective. Journal of Consumer Research,10, 319-329. https://doi.org/10.1086/208971

Solomon, M. R. (2017). Consumer behavior: buying, having, and being (12 ed.). Pearson: Prentice Hall.

Simon, H.A., (1972). Theories of bounded rationality. In C. B. McGuire \& R. Radner (Eds.), Decision and organization. NorthHolland, Amsterdam.

Sirgy, M. J., Grewal, D., Mangleburg, T. F., Park, J., Chon, K. S., \& Claiborne, C. B., et al. (1997). Assessing the predictive validity of two methods of measuring self-image congruence. The Journal of the Academy of Marketing Science, 25(3), 229-241. https://doi.org/10.1177/0092070397253004

Sirgy, M. J., \& Samli, C. (2000). A path analytic model of store loyalty involving self-concept, store image, socioeconomic status, and geographic loyalty. The Journal of the Academy of Marketing, 2(31), 83-90. Klaipeda: Klaipedos Universitetas. Retrieved from https://etalpykla.lituanistikadb.lt/object/LT-LDB-0001:J.04 2005 1367152773697/

Stankevičienè, J., \& Butkutè, R. (2008). Vartotojų elgsenos ypatumai prabangos prekių kontekete. Social Research, 4(14), $121-131$. Retrieved from http://su.lt/bylos/mokslo_leidiniai/soc_tyrimai/2008_14/stankeviciene.pdf

Stephen, A. (2016). The role of digital and social media marketing in consumer behaviour. Current Opinion in Psychology, 10, $17-$ 21. https://doi 10.25019/mdke/7.1.05

Stolz, J., \& Usunier, J. C. (2018). Religions as brands? Religion and spirituality in consumer society. Journal of Management, Spirituality \& Religion, 16, 6-31. https://doi.org/10.1080/14766086.2018.1445008

Szmigin, I., \& Carrigan, M. (2006). Exploring the dimensions of ethical consumption. European Advances in Consumer Research, 7, 608-613. http://acrwebsite.org/volumes/13699/eacr/vol7/E-07

Tangsupwattana, W., \& Liu, X. (2018). Effect of emotional experience on symbolic consumption in Generation Y consumers. Marketing Intelligence \& Planning, 36(5), 514-527. https://doi.org/10.1108/MIP-11-2017-0316

Terry L., Childers, C. L., Carr, J. \& Peck, S. C. (2001). Hedonic and utilitarian motivations for online retail shopping behavior. Journal of Retailing, 77(4), 511-535. https://doi10.1016/S0022-4359(01)00056-2.

Teller, C., Reutterer, T., Schnedlitz, P. (2008). Hedonic and utilitarian shopper types in evolved and created retail agglomerations. The International Review of Retail, Distribution and Consumer Research, 18(3), 283-309.

Tian, K., \& Belk, R. W. (2005). Extended self and possessions in the workplace. Consumeres, 32, 297-310. https://doi.org/10.1086/432239

Thompson, H. P. M. (1999). Brand spirit: how cause related marketing builds brands. Chichester: Wiley.

Tilich, P., \& Kimball, R. C. (2015). The nature of religious language in theology of culture. Oxford University Press.

Tiwari, K \& Rajendra, S. (2012). Perceived impact of ingredient branding on host brand equity. Journal of Marketing and Management, 3(1), 60-77. https://doi.org/10.1509/jmkg.66.1.73.18450

Twitchell, J. B. (1999). Lead us into temptation. New York (N.Y.): Chichester, West Sussex.

Walters, C. G. (1978). Consumer behavior, theory and practice. Homewood: R. D. Irwin, Australia.

Zikiene, K., \& Bakanauskas, A. (2009). Research of factors influencing loyal customer switching behavior. Organizaciju vadyba: sisteminiai tyrimai, 52, 153-170. Retrieved from https:/www.ceeol.com/search/article-detail?id=95833

Zang, B., \& Kim, J. (2013). Luxury fashion consumption in China: Factors affecting attitude and purchase intent. Journal of Retailing and Consumer Services, 20, 68-79. https://doi.org/10.1016/j.jretconser.2012.10.007 